\title{
L-Ascorbic acid and $\alpha$-Tocopherol to protect against arsenic trioxide induced oxidative stress in $\mathrm{H9c2}$ cardiomyocytes
}

\author{
Vineetha R.C. ${ }^{1}$, Abhilash S. ${ }^{1}$, R. Harikumaran Nair ${ }^{1 *}$

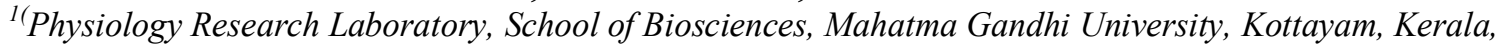 \\ India-686560)
}

\begin{abstract}
Arsenic has been used as a therapeutic agent against various diseases right from the historical periods. Arsenic trioxide $\left(\mathrm{As}_{2} \mathrm{O}_{3}\right.$ ), a first line chemotherapeutic against Acute Promyelocytic Leukemia (APL), is well known for its cardiotoxicity. We hypothesized that combination of drug and protective molecules can be used for reducing the side effects of chemotherapeutics. The present study evaluates the protective role of $L$ ascorbic acid (L-AA) and $\alpha$-Tocopherol $(\alpha-T O C)$ against oxidative stress in H9c2 cardiomyocytes induced by $\mathrm{As}_{2} \mathrm{O}_{3}$. Clinically relevant concentration of arsenic trioxide induces cytotoxicity in cardiac cells. Treatment with antioxidant vitamins significantly reduced the cell death and apoptosis in $\mathrm{H} 9 \mathrm{c} 2 \mathrm{cell}$. The activity of antioxidant enzymes such as catalase and the concentration of reduced glutathione, which was lowered due to $\mathrm{As}_{2} \mathrm{O}_{3}$ treatment, were found to be increased in cells co treated with L-AA and $\alpha$-TOC. The treatment with antioxidant vitamins also reduced lactate dehydrogenase release in cells. The overall results clearly indicate the protective potential of $L-A A$ and $\alpha-T O C$ against arsenic induced chemotherapeutic stress on cardiomyocytes.
\end{abstract}

Keywords: Arsenic trioxide, Cardiotoxicity, H9c2 cardiomyocytes, L-Ascorbic acid, Oxidative stress, $\alpha$ Tocopherol

\section{Introduction}

Acute promyelocytic leukemia (APL) is a distinctive subtype of acute myelogenous leukemia (AML) and accounts for approximately $10 \%$ to $15 \%$ of adult myeloid leukemia.[1] APL is a disease in which cancer cells are found in blood and bone marrow. Treatment for leukemia is complex and depends on a number of factors including the type of leukemia, the extent of the disease and whether the leukemia has been treated before. Arsenic is an environmental toxin but it has also been used in medicine as a therapeutic agent for more than 2400 years.[2] Inorganic arsenic is now a first choice cancer chemotherapeutic against certain leukemia.[3],[4] The US Food and Drug Administration (FDA) approved the use of Trisenox brand arsenic trioxide $\left(\mathrm{As}_{2} \mathrm{O}_{3}\right)$ for the treatment of acute promyelocytic leukemia in September 2000.[5]

Most APL cases are characterized by a $t(15 ; 17)$ translocation that fuses the promyelocytic leukemia (PML) gene on chromosome 15 to the retinoic acid receptor $\alpha$ (RAR $\alpha$ ) gene on chromosome 17, resulting in the formation of the oncoprotein promyelocytic leukemia/retinoic acid receptor (PML-RAR $\alpha$ ) fusion protein. Arsenic induces differentiation through degradation of the fusion protein.[6],[7],[8] Due to its toxic nature, arsenic trioxide carries significant health risks. It can cause QT interval prolongation which can lead to torsades de pointes and sudden death. Eliminating the cardiotoxicity induced by arsenic trioxide is expected to have a tremendous impact on the treatment of acute promyelocytic leukaemia. Studies showed that arsenic trioxide $\left(\mathrm{As}_{2} \mathrm{O}_{3}\right)$ induces cell death in cancer cells by the generation of reactive oxygen species, cell cycle arrest, and activation of apoptotic pathways.[9],[10]The same mode of action in normal cells causes cell toxicity which is fatal for cellular survival.

Various antioxidant molecules are found to be effective in counteracting free radical induced damage that occur due to arsenic chemotherapy.[11] L- Ascorbic acid (L- AA) or Vitamin C, a low molecular weight, water- soluble antioxidant vitamin, possesses pro oxidant properties that helps the body's own free radical defense mechanism and destroy tumors in their initial stages. Evidences showed that ascorbic acid can improve mitochondrial function by improving the thiol status; thereby preventing reactive oxygen species - mediated damage. Ascorbic acid is not likely to increase the antineoplastic activity of arsenic but could provide protection to both normal and neoplastic cells.[2]

$\alpha$-Tocopherol or Vitamin E, a lipid soluble vitamin, react with free radicals and ROS. The administration of $\alpha$-Tocopherol will decrease extend of lipid peroxidation; a major contributor to atherosclerosis and cardiovascular diseases. It can also function as a peroxyl radical scavenger that terminates chain reaction.[12],[13] $\alpha$-Tocopherol has been shown to protect against arsenic intoxication.[14]

In the present study we are evaluating the ameliorative effect of antioxidant vitamins against the oxidative stress induced by $\mathrm{As}_{2} \mathrm{O}_{3}$ in $\mathrm{H} 9 \mathrm{c} 2$ cardiomyocytes. 


\subsection{Reagents}

\section{Materials And Methods}

Arsenic trioxide $\left(\mathrm{As}_{2} \mathrm{O}_{3}\right)$, L-Ascorbic acid (L-AA), $\alpha$-Tocopherol $(\alpha-\mathrm{TOC})$, Acridine orange and Ethidium Bromide were purchased from Sigma (USA). Fetal Bovine Serum (FBS) was purchased from Invitrogen. 3-(4, 5, dimethylthiazol-2-yl)-2, 5, diphenyl tetrazolium bromide (MTT), dimethyl sulfoxide (DMSO), Dulbecco's modified Eagle's medium (DMEM), Trypsin - EDTA solution and other chemicals were purchased from Himedia Pvt Ltd (Mumbai, India).

\subsection{Cell culture and treatment}

H9c2 cardiomyocytes were obtained from National Centre for Cell Science (NCCS), Pune, India. Cells were cultured in Dulbecco's Modified Eagle's Medium (DMEM) supplemented with 10\% FBS and incubated at $37^{\circ} \mathrm{C}$ in humidified atmosphere in a $5 \% \mathrm{CO}_{2}$ incubator. Cells were passaged regularly and sub cultured to $80 \%$ confluence before the experiments. The experimental group consists of

(a) Control cells.

(b) Cells treated with $0.2 \%$ ethanol (Negative control) for 48 hours.

(c) Cells treated with $10 \mu \mathrm{M} \mathrm{As}_{2} \mathrm{O}_{3}$ for 48 hours.

(d) Cells treated with $100 \mu \mathrm{M} \mathrm{L}$-Ascorbic acid for 48 hours.

(e) Cells treated with $50 \mu \mathrm{M} \alpha$-Tocopherol for 48 hours.

(f) Cells treated with $10 \mu \mathrm{M} \mathrm{As}_{2} \mathrm{O}_{3}, 100 \mu \mathrm{M}$ L-Ascorbic acid and $50 \mu \mathrm{M} \alpha$-Tocopherol for 48 hours.

\subsection{Morphological Analysis}

After 48 hours of treatment with $\mathrm{As}_{2} \mathrm{O}_{3}$, L-AA and $\alpha$-TOC, the morphology of $\mathrm{H} 9 \mathrm{c} 2$ cardiomyocytes were observed using an inverted phase contrast microscope (Olympus CKX41 with Optika Pro5 camera) at $10 \mathrm{x}$ magnification.

\subsection{Cell viability assay}

Cell viability of various experimental groups was determined after 48 hours of incubation by MTT assay. MTT is a colorimetric assay that measures the reduction of yellow 3-(4,5 dimethythiazol-2-yl)-2, 5diphenyl tetrazolium bromide (MTT) by mitochondrial succinate dehydrogenase. The MTT enters the cells and passes into the mitochondria where it is reduced to an insoluble, coloured formazan product. The cells are then solubilised with an organic solvent dimethyl sulfoxide and the released, solubilised formazan product was measured using an ELISA plate reader (Erba Manheim, Germany) at $540 \mathrm{~nm} .[15]$

\subsection{Lactate Dehydrogenase Release Assay}

Lactate dehydrogenase (LDH) is used as a quantitative marker enzyme for the intact cell. Measurement of lactate dehydrogenase release is an important and frequently applied test for cell damage. LDH leakage assay was performed with cell free supernatant mixed with potassium phosphate buffer, 6mM NADH solution and sodium pyruvate solution. The OD was recorded at $340 \mathrm{~nm}$ in a spectrophotometer.[16]

\subsection{Lipid peroxidation Assay}

Lipid peroxidation in cell cultures was estimated by measuring the formation of malondialdehyde (MDA). The treated cells were centrifuged at $4000 \mathrm{rpm}$ for 10 minutes. Cell lysis buffer was added to the pellet and kept for 30 minutes incubation at $4{ }^{\circ} \mathrm{C} .70 \%$ alcohol and $1 \%$ TBA were added to each of the tubes and were kept in a boiling water bath for 20 minutes. Acetone was added to all the test tubes after cooling to room temperature and the absorbance was read at $535 \mathrm{~nm} .[17]$

\subsection{Fluorescent microscopy Observations}

Cells were labeled with Acridine Orange/ Ethidium Bromide (AO/EB) to detect apoptosis. A mixture of AO $(100 \mu \mathrm{g} / \mathrm{ml})$ and EB $(100 \mu \mathrm{g} / \mathrm{ml})$ were added and incubated at room temperature for $10 \mathrm{~min}$. After washing with PBS the cells were observed under a fluorescent microscope (Olympus CKX41 with Optika Pro5 camera).[18]

\subsection{Determination of antioxidant enzyme activities}

Activities of antioxidant enzymes like reduced glutathione (GSH) and Catalase (CAT) were assayed according to the method of Moron et al[19] and Sinha et al[20] respectively.

\subsection{Estimation of Nitrate by Griess method}


H9c2 cells were plated in a 96-well plate $\left(1 \times 10^{5}\right.$ cells/ well), and incubated with appropriate concentrations of $\mathrm{As}_{2} \mathrm{O}_{3}$, L-AA and $\alpha$-TOC for 48 hours. The concentration of nitrate was determined using Griess reagent $(1 \%$ sulphanilamide, $0.1 \%$ naphthylethylenediamine dichloride and $2 \%$ phosphoric acid). The amount of nitrate present in various samples was measured at 540nm.[21]

\subsection{Statistical Analysis}

Data were collected from repeated experiments and the results were presented as mean ( \pm Standard deviation). Data were subjected to one-way analysis of variance (ANOVA) using Origin, version 7, Origin Lab Corporation, Northampton, USA. $\mathrm{P}<0.05$ was considered to be statistically significant.

\subsection{Effect of Arsenic trioxide on cell morphology:-}

\section{Results}

Fig 1B. showed that treatment with $\mathrm{As}_{2} \mathrm{O}_{3}(10 \mu \mathrm{M})$ induced changes in the morphology of $\mathrm{H} 9 \mathrm{c} 2$ cells such as shrinkage, rounding up detachment from the plate when compared with the normal cells (Fig 1A). Combination treatment using L-Ascorbic $(100 \mu \mathrm{M})$ and $\alpha$-Tocopherol $(50 \mu \mathrm{M})$ were found to be effective in maintaining the normal cell morphology (Fig 1F, 1G, 1H).
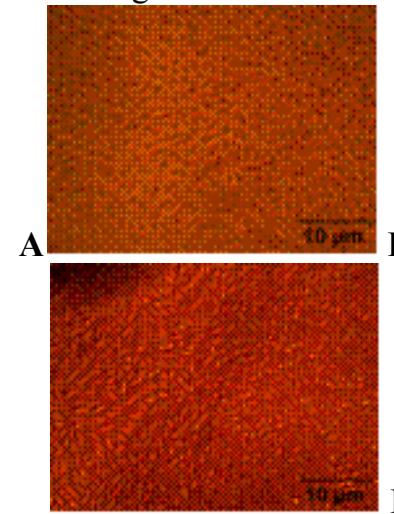
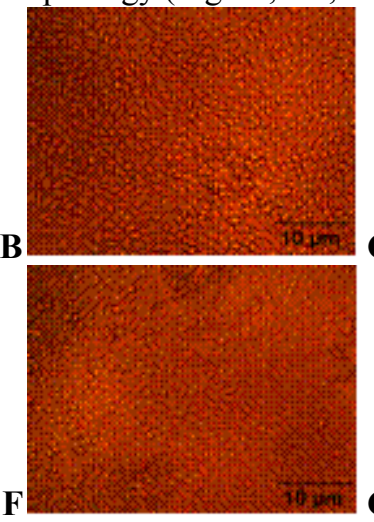
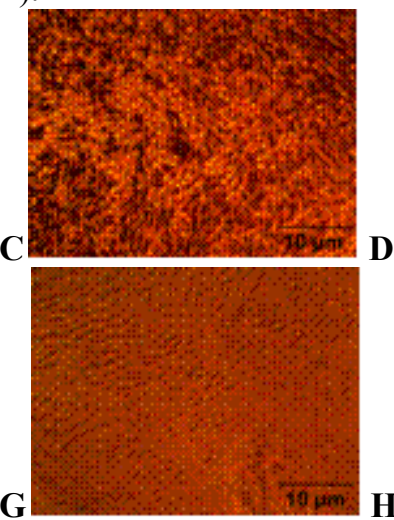
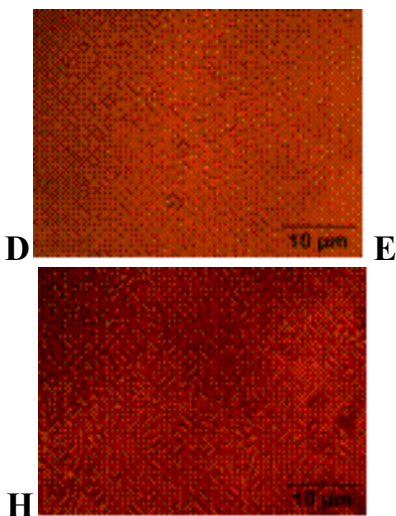

Fig 1. Morphological Analysis of $\mathrm{H9c2}$ cells after 48 Hours of treatment. (A) Control cells (B) Cells treated with $0.2 \%$ Ethanol (C) Cells treated with $10 \mu \mathrm{M} \mathrm{As}_{2} \mathrm{O}_{3}$ (D) Cells treated with $100 \mu \mathrm{M}$ L-AA (E) Cells treated with $50 \mu \mathrm{M} \alpha$-TOC (F) Cells treated with $10 \mu \mathrm{M} \mathrm{As} \mathrm{O}_{2}$ and $100 \mu \mathrm{M} \mathrm{L}$-AA (G) Cells treated with $10 \mu \mathrm{M} \mathrm{As}_{2} \mathrm{O}_{3}$ and $50 \mu \mathrm{M} \alpha$-TOC $(\mathrm{H})$ Cells treated with $10 \mu \mathrm{M} \mathrm{As}_{2} \mathrm{O}_{3}, 100 \mu \mathrm{M}$ L-AA and $50 \mu \mathrm{M} \alpha$-TOC (Original magnification $\mathrm{x} 10)$.

\subsection{Effect of $\mathrm{L}$ - Ascorbic Acid and $\alpha$-Tocopherol on arsenic trioxide induced cytotoxicity in $\mathrm{H} 9 \mathrm{c} 2$ cells.}

As shown in Fig 2., $10 \mu \mathrm{M} \mathrm{As}_{2} \mathrm{O}_{3}$ reduced the viability of $\mathrm{H} 9 \mathrm{c} 2$ cells after 48 hours of treatment. An increase in the percentage of viability was observed in cells treated with a combination of $\mathrm{As}_{2} \mathrm{O}_{3}$ and L-AA and $\mathrm{As}_{2} \mathrm{O}_{3}$ and $\alpha$-TOC.Combined treatment with $100 \mu \mathrm{M}$ L-Ascorbic acid and $50 \mu \mathrm{M} \alpha$-Tocopherol with $\mathrm{As}_{2} \mathrm{O}_{3}$ significantly increased the cell viability when compared with all other groups (Fig. 2).

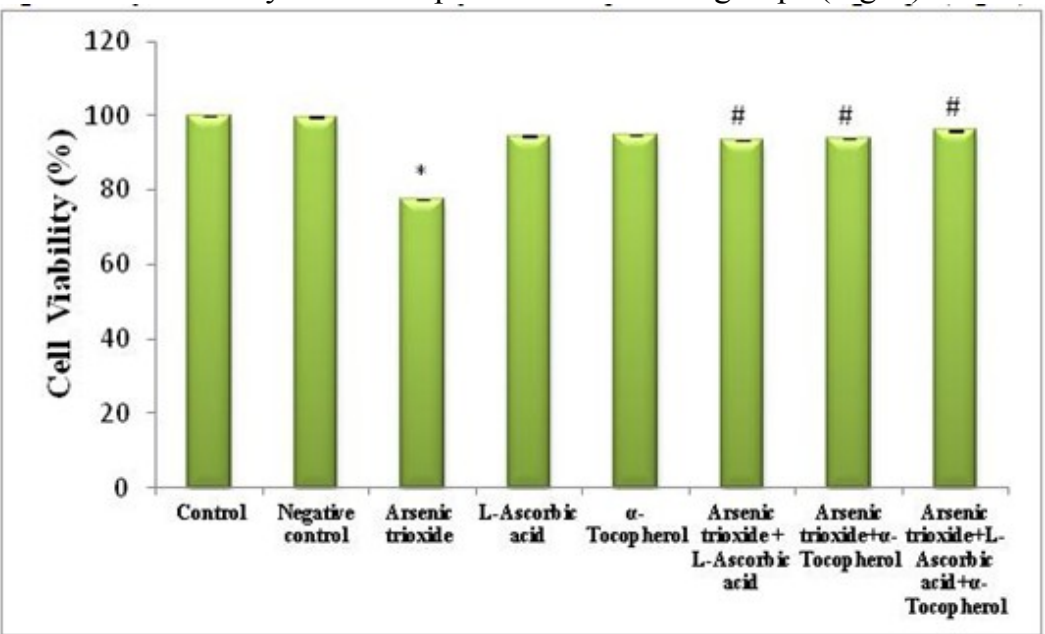

Fig 2. MTT Assay after 48 hours of treatment. Data represented as mean $\pm \mathrm{SD},{ }^{*} \mathrm{p}<0.05$ versus normal control and ${ }^{\#} \mathrm{p}<0.05$ versus $\mathrm{As}_{2} \mathrm{O}_{3}$ treated groups.

3.3 L- Ascorbic Acid and $\alpha$-Tocopherol reduces LDH release in Arsenic trioxide-treated H9c2 cells 
The cellular LDH release was markedly increased in cells treated with $\mathrm{As}_{2} \mathrm{O}_{3}(10 \mu \mathrm{M})$ whereas combined treatment with L-Ascorbic acid $(100 \mu \mathrm{M})$ and $\alpha$-Tocopherol $(50 \mu \mathrm{M})$ with $\mathrm{As}_{2} \mathrm{O}_{3}$ significantly reduced the LDH leakage (Fig. 3).

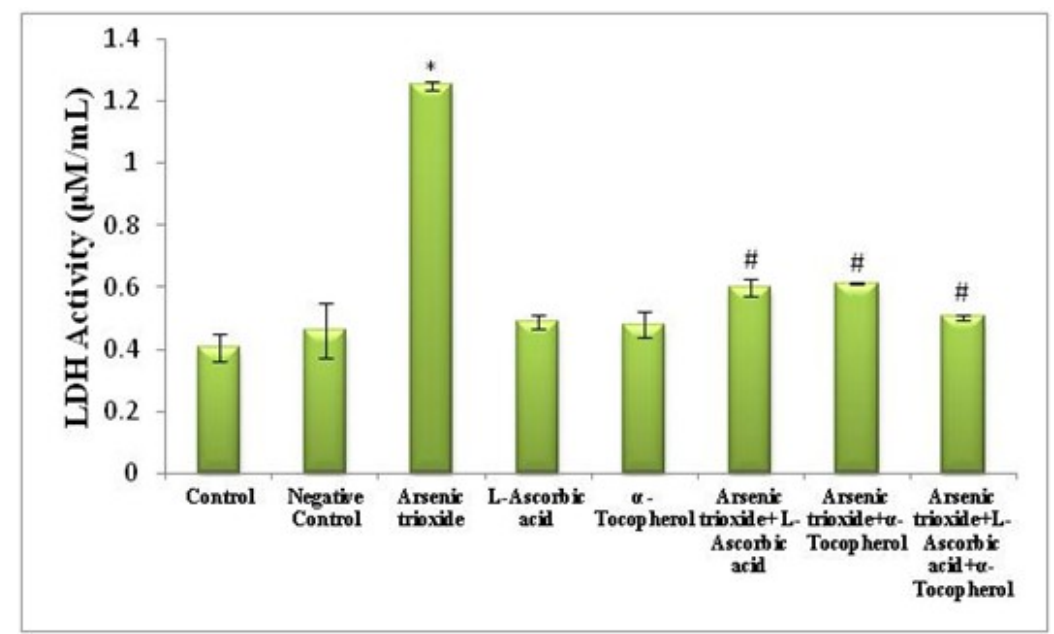

Fig 3. LDH leakage. Data represented as mean $\pm \mathrm{SD},{ }^{*} \mathrm{p}<0.05$ versus normal control and ${ }^{\#} \mathrm{p}<0.05$ versus $\mathrm{As}_{2} \mathrm{O}_{3}$ treated groups.

\subsection{L-Ascorbic acid and $\alpha$-Tocopherol lowers lipid peroxidation in $\mathrm{As}_{2} \mathrm{O}_{3}$ treated cells}

A high level of lipid peroxidation was observed in $\mathrm{H} 9 \mathrm{c} 2$ cells treated with $10 \mu \mathrm{M} \mathrm{As} \mathrm{O}_{3}$. In the presence of $100 \mu \mathrm{M}$ L-Ascorbic acid and $50 \mu \mathrm{M} \alpha$-Tocopherol, the malondialdehyde (MDA) release was markedly reduced. This indicates that administration of antioxidant vitamins significantly reduced the extent of lipid peroxidation caused by arsenic trioxide. (Fig. 4).

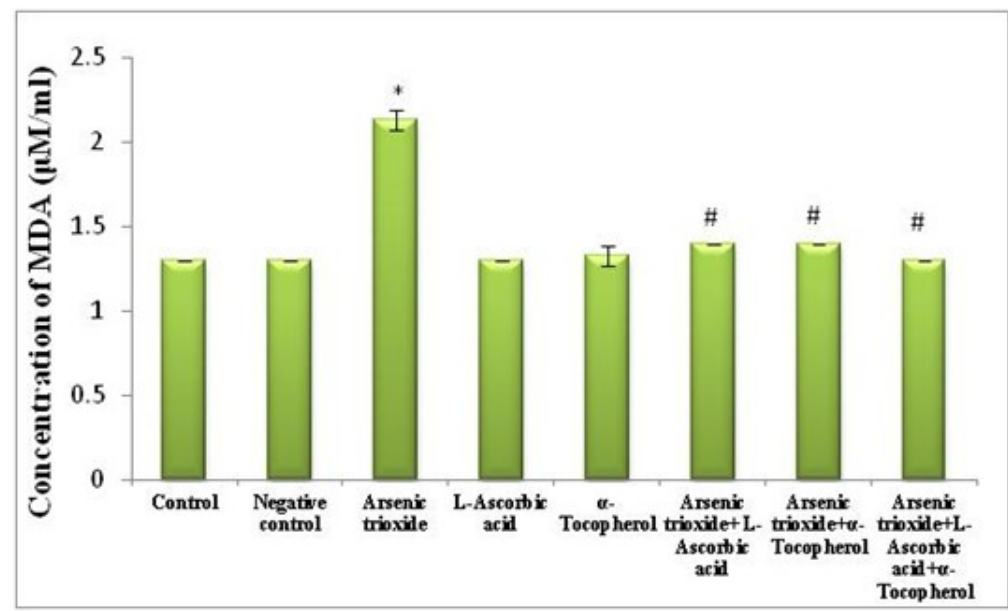

Fig 4. Lipid peroxidation assay. Data represented as mean $\pm S D,{ }^{*} p<0.05$ versus normal control and ${ }^{\#} p<0.05$ versus $\mathrm{As}_{2} \mathrm{O}_{3}$ treated groups.

\section{5 $\mathrm{As}_{2} \mathrm{O}_{3}$ induced apoptosis can be reduced by co-treatment with L-Ascorbic acid and $\alpha$-Tocopherol}

The cells were observed under a fluorescent microscope at 10x magnification. Viable cells appeared as green and apoptotic cells as orange. Morphological changes such as cell shrinkage and nuclear condensation were observed in the cells treated with arsenic trioxide when compared with the control cells (Fig. 5A, 5C). $\mathrm{AO} / \mathrm{EB}$ staining showed that combination treatment using antioxidant vitamins such as L-Ascorbic acid and $\alpha$ Tocopherol was effective to protect the cells from apoptosis (Fig. 5F, 5G, 5H).
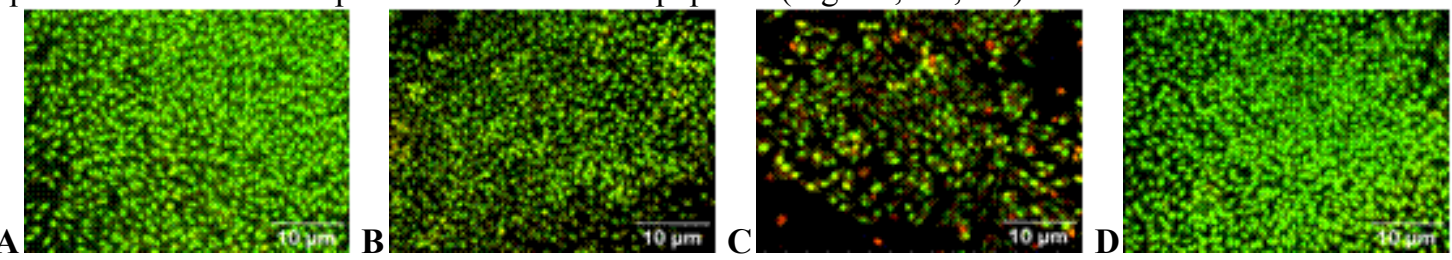

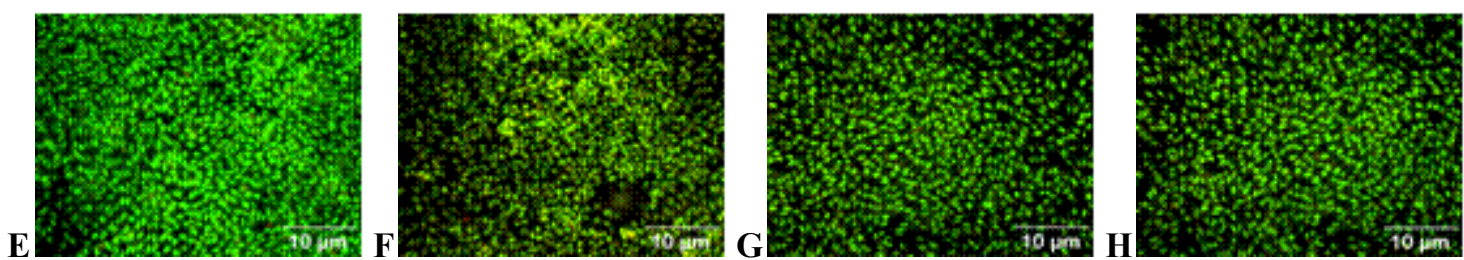

Fig 5. Morphological observation of H9c2 cells by AO/EB staining. (A) Control cells (B) Cells treated with $0.2 \%$ ethanol (C) Cells treated with $10 \mu \mathrm{M} \mathrm{As}_{2} \mathrm{O}_{3}$ (D) Cells treated with $100 \mu \mathrm{M}$ L-AA (E) Cells treated with $50 \mu \mathrm{M} \alpha-\mathrm{TOC}(\mathrm{F})$ Cells treated with $10 \mu \mathrm{M} \mathrm{As}_{2} \mathrm{O}_{3}$ and $100 \mu \mathrm{M} \mathrm{L-AA}(\mathrm{g})$ Cells treated with $10 \mu \mathrm{M} \mathrm{As} \mathrm{O}_{3}$ and $50 \mu \mathrm{M} \alpha-\mathrm{TOC}(\mathrm{h})$ Cells treated

\subsection{Antioxidant Status} with $10 \mu \mathrm{M} \mathrm{As} \mathrm{O}_{3}, 100 \mu \mathrm{M}$ L-AA and $50 \mu \mathrm{M} \alpha$-TOC (original magnification $\mathrm{x} 10$ ).

The activity of reduced glutathione (GSH) was found to be significantly reduced by treatment with 10 $\mu \mathrm{M}$ concentration of $\mathrm{As}_{2} \mathrm{O}_{3}$ when compared to the untreated cells. Co-treatment with $100 \mu \mathrm{M} \mathrm{L}-\mathrm{AA}$ and $50 \mu \mathrm{M}$ $\alpha$-TOC significantly reduced the inhibition of GSH activity caused by arsenic trioxide (Fig. 6A). Similarly, the catalase (CAT) activity was also inhibited significantly by $\mathrm{As}_{2} \mathrm{O}_{3}$ (Fig. 6B). The combination treatment with LAA and $\alpha-$ TOC in these cells also reduced the catalase inhibition by arsenic trioxide treated cells.

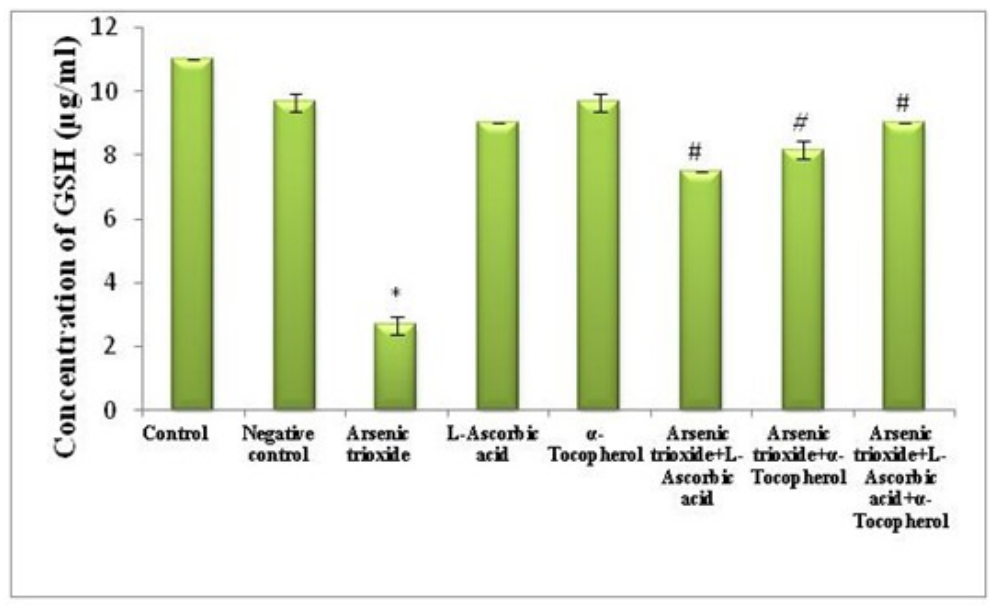

Fig 6A. Effect of arsenic trioxide, L-Ascorbic acid and $\alpha$-Tocopherol on reduced glutathione level. Data represented as mean $\pm S D,{ }^{*} p<0.05$ versus normal control and ${ }^{\#} p<0.05$ versus $\mathrm{As}_{2} \mathrm{O}_{3}$ treated groups.

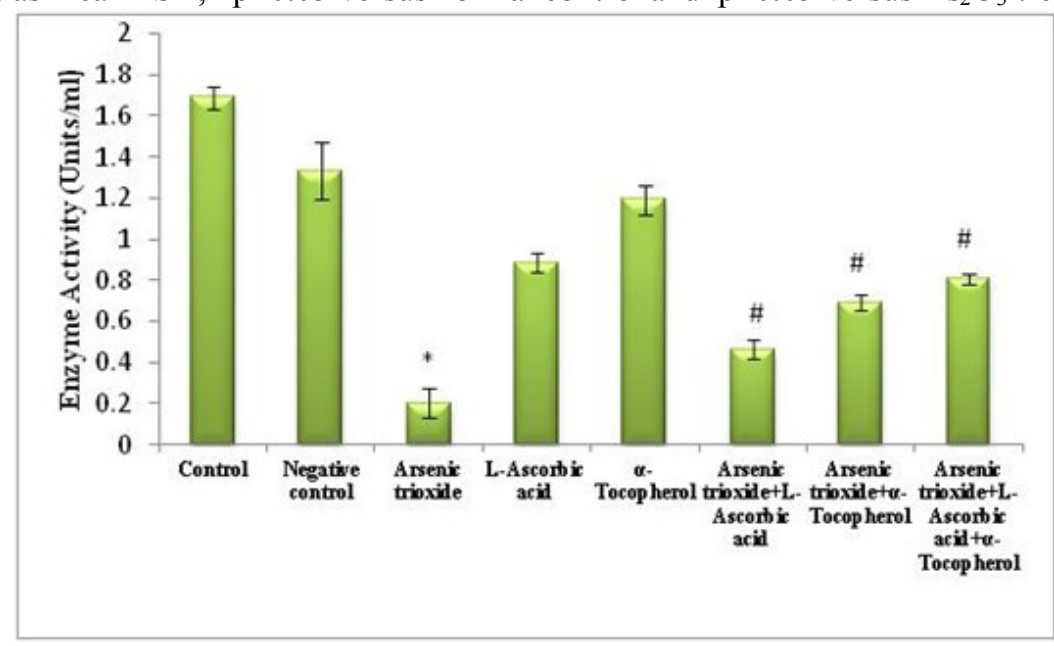

Fig 6B. Effect of arsenic trioxide, $L$-Ascorbic acid and $\alpha$-Tocopherol on catalase activity. Data represented as mean $\pm \mathrm{SD},{ }^{*} \mathrm{p}<0.05$ versus normal control and ${ }^{*} \mathrm{p}<0.05$ versus $\mathrm{As}_{2} \mathrm{O}_{3}$ treated groups.

\subsection{Determination of Nitrate levels}

The nitrate levels of various experimental groups were estimated using Griess reagent. The amount of nitrate released was found to be significantly higher in Arsenic trioxide treated cells when compared with the control cells. Fig 7 showed that the combination of L-AA and $\alpha$-TOC with arsenic trioxide significantly reduced the level of nitrate released. 


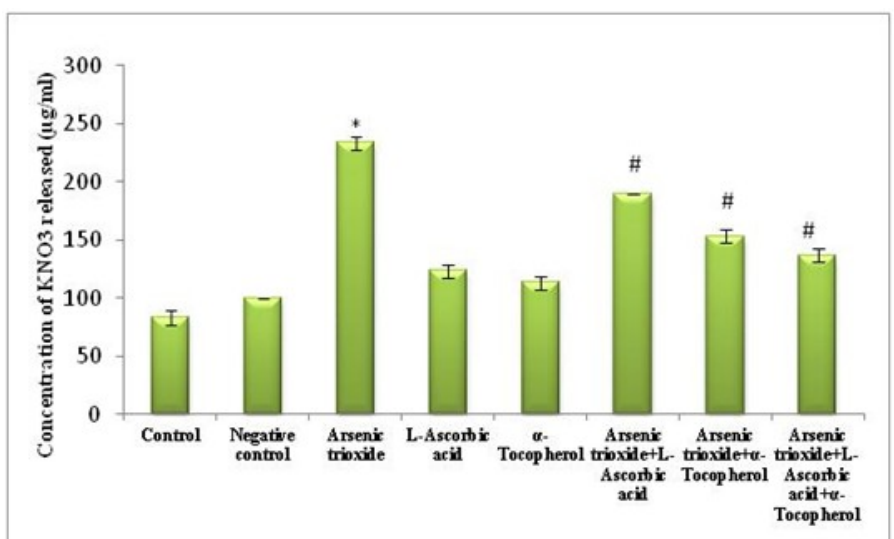

Fig 7. Effect of arsenic trioxide, L-Ascorbic acid and $\alpha$-Tocopherol on the nitrate level. Data represented as mean $\pm \mathrm{SD},{ }^{*} \mathrm{p}<0.05$ versus normal control and ${ }^{\#} \mathrm{p}<0.05$ versus $\mathrm{As}_{2} \mathrm{O}_{3}$ treated groups.

\section{Discussion}

The current study has shown the protective efficacy of L-Ascorbic acid and $\alpha$-Tocopherol against arsenic trioxide induced oxidative stress in $\mathrm{H} 9 \mathrm{c} 2$ cardiomyocytes. H9c2 is a clonal cell line derived from fetal rat heart and is morphologically similar to embryonic cardiomyocytes.[22]

Exposure of clinically relevant concentration of $\mathrm{As}_{2} \mathrm{O}_{3}$ induces apoptosis in $\mathrm{H} 9 \mathrm{c} 2$ cardiomyocytes. The mechanism by which $\mathrm{As}_{2} \mathrm{O}_{3}$ induces cell death is the favorable chemical reaction between arsenic and thiol groups within a protein. The valence orbitals of arsenic have a better affinity to sulfur than with oxygen, leading to As-thiolate bond formation with the release of water.[23] It is believed that low or physiologic doses of LAscorbic acid were not cytotoxic, and is beneficial in both cardiovascular diseases and cancer.[24] The most active form of vitamin $\mathrm{E}, \alpha$-Tocopherol is an antioxidant which prevents the peroxidation of unsaturated fatty acids by scavenging lipophilic radicals within membranes.[25]These compounds have cardioprotective and hepatoprotective roles also. Thus, our study focuses on the protective efficacy of these antioxidant vitamins against $\mathrm{As}_{2} \mathrm{O}_{3}$-induced toxicity and oxidative stress in $\mathrm{H} 9 \mathrm{c} 2$ cells.

Results from the MTT, LDH and lipid peroxidation assays showed that $\mathrm{As}_{2} \mathrm{O}_{3}$ is cytotoxic to $\mathrm{H} 9 \mathrm{c} 2$ cardiomyocytes. In addition to these, morphological alterations due to $\mathrm{As}_{2} \mathrm{O}_{3}$ such as cell surface shrinkage followed by rounding up occur as a result of membrane damage. Reduction in the viability of cells was also observed. A combination of L-AA $(100 \mu \mathrm{M})$ and $\alpha$-TOC $(50 \mu \mathrm{M})$ was found to be effective against cytotoxicity at $10 \mu \mathrm{M}$ concentration of $\mathrm{As}_{2} \mathrm{O}_{3}$. Arsenic trioxide induces myocardial membrane damage which leads to an increase in the LDH leakage as indicated in the current study. A marked increase in the level of lipid peroxidation was observed in arsenic trioxide treated cells. $\mathrm{As}_{2} \mathrm{O}_{3}$ causes the formation of free radicals which directly attack the poly unsaturated fatty acids (PUFA) present in the cell membrane resulting in the formation of MDA which was biochemically quantified by lipid peroxidation assay. We observed a significant reduction in the LDH activity and lipid peroxidation in cells co-treated with L-Ascorbic acid and $\alpha$-tocopherol which may be due to the membrane protective activity exerted by these antioxidant vitamins.

Studies showed that apoptosis plays an important role in the progression of heart failure.[26]The present study indicates $\mathrm{As}_{2} \mathrm{O}_{3}$ induced apoptosis in cardiomyocytes, as observed from the AO/EB fluorescent double staining. The evaluation of antioxidant enzymes like GSH and CAT in arsenic trioxide-treated cells were found to be significantly lower. High levels of GSH are associated with cellular resistance to arsenic and decreasing intracellular GSH concentrations cause increased sensitivity to $\mathrm{As}_{2} \mathrm{O}_{3}$. GSH functions as the major auto-oxidant of the cells, scavenging free radicals and to inactivate toxins and chemotherapeutics. [27] Increased MDA production directly indicates a reduction in GSH Levels which results in elevated ROS production resulting in lipid peroxidation leading to membrane damage of cells. L-AA and $\alpha$-TOC was able to protect the enzymes from depletion by $\mathrm{As}_{2} \mathrm{O}_{3}$ mainly due to the antioxidant property exhibited by these vitamins.

The formation of reactive oxygen species and nitrogen species by $\mathrm{As}_{2} \mathrm{O}_{3}$ is one of the most studied mechanisms for arsenic induced toxicity.[28] An increased level of nitrate, a stable product of Nitric Oxide (NO) was also detected in $\mathrm{As}_{2} \mathrm{O}_{3}$ treated cells. This may play a major role in $\mathrm{As}_{2} \mathrm{O}_{3}$ induced apoptosis in $\mathrm{H} 9 \mathrm{c} 2$ cardiomyocytes. NO is a highly unstable free radical produced by the enzyme Nitric Oxide Synthases (NOS).[29] NO binds to cytochrome oxidase and can block the mitochondrial respiratory chain thereby induces apoptosis. It is believed that antioxidant vitamins such as L-AA and $\alpha$-TOC is beneficial in both cardiovascular diseases and cancer.[24] We suggest that these antioxidant vitamins reduces the cytotoxicity of $\mathrm{As}_{2} \mathrm{O}_{3}$ by quenching intracellular ROS and nitrate levels thereby reducing the level of lipid peroxidation and apoptosis.[30] 


\section{Conclusion}

The present study evaluates the protective effect of L-ascorbic acid and $\alpha$-Tocopherol against arsenic trioxide induced toxicity in H9c2 cardiomyocytes. From the current study, it is evident that co-treatment with antioxidant vitamins protected the cells from the toxic effects of arsenic trioxide. In conclusion, using an in vitro model of $\mathrm{H} 9 \mathrm{c} 2$ cells, we suggested that these antioxidant vitamins may be a valuable option for reducing the cardiac toxicity induced by arsenic trioxide thereby rising its effectiveness as a chemotherapeutic agent.

\section{Acknowledgements}

We thank the Department of Science and Technology (DST), New Delhi for rendering financial support for the work and the award of research fellowship (Reg No. IF120622, DST/ INSPIRE Fellowship/2012/584).

\section{References}

[1]. Tallman MS, Nabhan C, Feusner JH, Rowe JM. Acute promyelocytic leukemia: evolving therapeutic strategies: review. Blood. 2002; 99(3):759-67.

[2]. Karasavvas N, Carcamo JM, Stratis G, Golde DW. Vitamin C protects HL60 and U266 cells from arsenic toxicity. Blood. 2005; 105(10):4004-12.

[3]. Hede K. Chinese folk treatment reveals power of arsenic to treat cancer, new studies under way. J Natl Cancer Inst. 2007; 99(9): 667-8.

[4]. McNeely SC, Belshoff AC, Taylor BF, Fan TW, McCabe MJ Jr, Pinhas AR, States JC. Sensitivity to sodium arsenite in human melanoma cells depends upon susceptibility to arsenite-induced mitotic arrest. Toxicol Appl Pharmacol. 2008; 229(2):252-61.

[5]. Barbey JT. Cardiac toxicity of arsenic trioxide: Review. Blood. 2001; 98(5): 1632

[6]. Lanotte M, Martin-Thouvenin V, Najman S, Balerini P, Valensi F, Berger R. NB4, a maturation inducible cell line with t(15;17) marker isolated from a human acute promyelocytic leukemia (M3). Blood. 199; 77(5): 1080-6.

[7]. Dyck JA, Maul GG, Miller WH Jr, Chen JD, Kakizuka A, Evans RM. A novel macromolecular structure is a target of the promyelocyte-retinoic acid receptor oncoprotein. Cell. 1994; 76(2): 333-43.

[8]. Wang ZG, Ruggero D, Ronchetti S, Zhong S, Gaboli M, Rivi R, Pandolfi PP. PML is essential for multiple apoptotic pathways. Nat Genet. 1998; 20(3): 266-72.

[9]. Harris GK, Shi X. Signaling by carcinogenic metals and metal-induced reactive oxygen species: Review. Mutat Res. 2000; 533(12): $183-200$.

[10]. Shi H, Hudson LG, Ding W, Wang S, Cooper KL, Liu S, Chen Y, Shi X, Liu KJ. Arsenite causes DNA damage in keratinocytes via generation of hydroxyl radicals. Chem Res Toxicol. 2004; 17(7): 871-8.

[11]. Ramanathan K, Anusuyadevi M, Shila S, Panneerselvam C. Ascorbic acid and alpha-tocopherol as potent modulators of apoptosis on arsenic induced toxicity in rats. Toxicol Lett. 2005; 156(2): 297-306.

[12]. Tappel AL.Vitamin E as the biological lipid antioxidant. Vitamins \& Hormones. 1962; 20: 493-510.

[13]. Tappel AL. Vitamin E and Selenium Protection from in vivo lipid peroxidation. Annals of the New York Academy of Sciences. 1980; 355(1), 18-31.

[14]. Mittal M, Flora SJ. Vitamin E supplementation protects oxidative stress during arsenic and fluoride antagonism in male mice. Drug Chem Toxicol. 2007; 30(3):263-81.

[15]. Arung ET, Shimizu K, Kondo R. Evaluation of isolated compounds from wood of Artocarpus heterophyllus as a cosmetic agent. Wood Res. J. 2010; 1(1).

[16]. Renner K, Amberger A, Konwalinka G, Kofler R, Gnaiger E. Changes of mitochondrial respiration, mitochondrial content and cell size after induction of apoptosis in leukemia cells. Biochim. Biophys. Acta. 2003; 1642: 115- 123.

[17]. Ohkawa H, Ohishi N, Yagi K. Assay for lipid peroxides in animal tissues by thiobarbituric acid reaction. An. Biochem. 1979; 95 : 351-358.

[18]. Zhang JH, Yu J, Li WX, Cheng CP. Evaluation of $\mathrm{Mn}^{2+}$ stimulated and $\mathrm{Zn}^{2+}$ inhibited apoptosis in rat corpus luteal cells by flow cytometry and fluorochromes staining. Cin. J. Physiol. 1998; 41 (2): 121 - 126.

[19]. Moron MS, Depierre JW, Mannervik B. Levels of glutathione, glutathione reductase and glutathione S-transferase activities in rat lung and liver. Biochim Biophys Acta. 1979; 582(1): 67-78.

[20]. Sinha AK. Colorimetric assay of catalase. Anal Biochem. 1972; 47(2): 389-94.

[21]. Lepoivre M, Chenais B, Yapo A, Lemaire G, Thelander L, Tenu JP. Alterations of ribonucleotide reductase activity following induction of the nitrite-generating pathway in adenocarcinoma cells. J Biol Chem. 1990; 265(24): 14143-9.

[22]. Sipido KR, Wier WG. Flux of $\mathrm{Ca}^{2+}$ across the sarcoplasmic reticulum of guinea-pig cardiac cells during excitation-contraction coupling. J Physiol. 1991; 435: 605-30.

[23]. Aposhian HV. In: Hodgson E, Bend JR, Philpot RM, editors. Biochemical toxicology of arsenic. Reviews in Biochemical Toxicology.1989; 265-99.

[24]. Verrax J, Calderon PB. The controversial place of vitamin C in cancer treatment. Biochemical pharmacology. $2008 ; 76: 1644-1652$.

[25]. Boscoboinik D, Szewczyk A, Hensey CS, and Ami A. Inhibition of Cell Proliferation by $\alpha$-Tocopherol Role of Protein Kinase C. The Journal of Biological Chemistry. 1991; 266 (10): 6188-6194

[26]. Grazette LP, Rosenzweig A. Role of apoptosis in heart failure. Heart Fail Clin. 2005; 1:251-61.

[27]. Scott N, Hatlelid KM, MacKenzie NE, Carter DE. Reactions of arsenic (III) and arsenic (V) species with glutathione. Chem Res Toxicol. 1993; 6(1): 102-6.

[28]. Kitchin KT, Wallace K. The role of protein binding of trivalent arsenicals in arsenic carcinogenesis and toxicity: Review. J Inorg Biochem. 2008; 102(3): 532-9.

[29]. Li H, Kolluri SK, Gu J, Dawson MI, Cao X, Hobbs PD, Lin B, Chen G, Lu J, Lin F, Xie Z, Fontana JA, Reed JC, Zhang X. Cytochrome c release and apoptosis induced by mitochondrial targeting of nuclear orphan receptor TR3. Science. 2000; 289: 11591164.

[30]. Brown GC. Regulation of mitochondrial respiration by nitric oxide inhibition of cytochrome c oxidase. Biochim Biophys Acta. 2001; 1504: 46-57. 